\title{
Quality of Soybean Seeds Cultivated on Different Potassium Fertilization Management
}

\author{
Lorena M. Lara ${ }^{1}$, Michel Esper Neto ${ }^{1}$, Guilherme F. Chilante ${ }^{1}$, Tadeu T. Inoue ${ }^{2}$, Alessandro L. Braccini ${ }^{2}$ \\ \& Marcelo A. Batista ${ }^{2}$ \\ ${ }^{1}$ Post-Graduate in Agronomy, Maringá State University, Maringá, PR, Brazil \\ ${ }^{2}$ Agronomy Department, Maringá State University, Maringá, PR, Brazil \\ Correspondence: Michel Esper Neto, Post-Graduate in Agronomy, Maringá State University, Colombo Avenue, n. \\ 5790-Bloco J57, $1^{\circ}$ Piso, 87020-900, Maringá, Paraná, Brazil. Tel: 55-44-3011-1375. E-mail: \\ michelesper14@gmail.com
}

Received: July 17, $2018 \quad$ Accepted: August 16, $2018 \quad$ Online Published: October 15, 2018

doi:10.5539/jas.v10n11p211 URL: https://doi.org/10.5539/jas.v10n11p211

\begin{abstract}
Soybean is one of the crops worldwide cultivated, and although it is usually commercialized quantitatively, qualitative characteristics of its production are highlighted, particularly oil and protein content, which is important for human and animal nutrition besides higher industrial yields in the synthesis of its derivatives. This study assessed the quality seed changes of soybean cultivated under different potassium rates in an Oxisol under no-tillage system in Floresta, Paraná State, Brazil. The experiment designed was in complete randomized blocks composed of a cross factorial $(5 \times 2)$ with four replicates. It was carried out in two growing seasons $(2016 / 2017$ and 2017/2018) totaling 40 experimental units. The rates $\left(0,40,80,120\right.$, and $160 \mathrm{~kg} \mathrm{ha}^{-1}$ of K) corresponded to the first factor and sowing fertilization $\left(0\right.$ and $30 \mathrm{~kg} \mathrm{ha}^{-1}$ of $\left.\mathrm{K}\right)$ was the second factor. Seed electrical conductivity, water content, seed $\mathrm{K}$ leaching, seed $\mathrm{K}$ content, oil and protein content, seed density, seed mass and yield were measured. The results indicated that $\mathrm{K}$ application for soybean may promote better quality seeds production, since electric conductivity, oil and water content and yield have increased in some conditions, although the sowing fertilization did not influence.
\end{abstract}

Keywords: electric conductivity, Glycine $\max$ (L). merr, sowing fertilization, maintenance fertilization

\section{Introduction}

Soybean [Glycine $\max (\mathrm{L})$. merr] is the most important cash crop in Brazil and in several countries around the world. In Brazil, soybean has been cultivated in all regions and its production complex is the main agribusiness productive chain. Brazilian soybean production is the second world's largest (CONAB, 2017). Due to versatility of its derivatives the demand for soybean grain is increasing every year by the external and domestic markets, consequently there is an expansion of the area cultivated with soybean on new agricultural frontiers. In addition, many investments are made to supply technologies to increase production by area (Linzmeyer Junior et al., 2008).

Despite grain yield requirement, there is still concern toward increasing grain quality used in human and animal nutrition, mainly related with protein and oil contents. These qualitative attributes may be linked to greater consumer acceptance and industry processing (Pipolo et al., 2015). However, quality variables are not taken into account in soybean commercialization, although they are important because depending on the oil and protein content of the seeds, the costs of soybean products may decrease or increase (Tanaka et al., 1995). Oil and protein contents are closely linked to genetic variability and environmental conditions (Westgate et al., 1999), as well as anthropic factors such as soil fertilization and plant nutrition. For example, Albrecht et al. (2008) found that simple human management, such as sowing time, can influence oil and protein content.

Among the elements involved in soybean fertilization and nutrition, potassium $(\mathrm{K})$ is the most abundant cation in plant tissue. The $\mathrm{K}$ nutrition plays an essential role in regulation of cellular osmotic potential. Furthermore, the element activates more than sixty enzymes, mostly involved in synthesis of sugar, starch and proteins. $\mathrm{K}$ is also responsible for stomatal opening and closing, which creates suitable conditions for the photosynthetic process and the gas exchanges (Marschner, 1995). K is still related to higher biotic and abiotic stress tolerance, such as 
Piezodorus guildinii (Cardoso et al., 2002), Cercospora kikuchii, Phomopsis sp. and Diaporthe phaseolorum $f$. sp. meridionalis (Basseto et al., 2007), low water availability (Esper Neto et al., 2018) and lodging.

According to Foloni and Rosolem (2008), soybean usually responds to potassium fertilization in tropical soils. On the other hand, some authors have shown that there is lack or no response in conditions above the critical level of K in soil (Guareschi et al., 2008; Bernardi et al., 2009; Gonçalves Júnior et al., 2010). Under these conditions, responses are subtle and often do not significantly increase yield. Some authors have found significant differences for $\mathrm{K}$ application in the soil by analyzing soybean seeds as in germination tests (Toledo et al., 2011), on K contents exported by seed (Serafim et al., 2012), on protein content and seed mass (Khan et al., 2004) and vigor seed (Petter et al., 2014). Nevertheless, the increase in $K$ seed exported would be more frequently observed in soils with K content less than $0.3 \mathrm{cmol}_{\mathrm{c}} \mathrm{dm}^{-3}$ (Sale \& Campbell, 1986; Serafim et al., 2012). Veiga et al. (2010) evaluated the influence of $K$ fertilization on the quality of soybean seed produced in soil with a mean $\mathrm{K}$ content of $0.2 \mathrm{cmol}_{\mathrm{c}} \mathrm{dm}^{-3}$ and did not find statistical significant differences. Regardless $\mathrm{K}$ rate applied Pedroso Neto and Rezende (2005), reported grain yield, protein, oil contents, and seed vigor were altered. These results agree with those observed by Snyder and Ashlock (1996) who mention seed quality may be impaired by K soil deficiency.

It is widely reported that $\mathrm{K}$ fertilization may influence the quality of soybean seeds, although the results are controversial due to exchangeable $\mathrm{K}$ in soil and environmental conditions of each region. Therefore, this study was based on the principle that soybean plants whose soil $\mathrm{K}$ is available are more tolerant to deleterious effects (biotic and abiotic) during their life cycle and will produce higher quality seeds and resistance, with an increase in crop yield. In this context, the mean goal of this study was to evaluate changes in the soybean seed quality in two growing seasons after the application of increasing $\mathrm{K}$ rates. In addition, we investigated the effects of $\mathrm{K}$ fertilization in soybean sowing with adequate levels of soil fertility.

\section{Materials and Methods}

This study was carried out in the experimental field of Technology Diffusion Unit (TDU) of Cooperativa Agroindustrial de Maringá (Cocamar) near Floresta, Paraná State (latitude $23^{\circ} 35^{\prime} 42^{\prime \prime}$ S, longitude 52 $04^{\prime} 02^{\prime \prime}$ W). The soil of the experimental area was classified as Oxisol. The field study was under no-tillage system during past 20 years, with successive crops of soybean and maize. The climate was classified as Cfa (Alvares et al., 2013).

The experiment was conducted out for two consecutive years with soybean in the 2016/2017 and 2017/2018 growing seasons. The studied treatments tested combinations of the following factors: $\mathrm{K}$ rates $(0,40,80,120$, and $\left.160 \mathrm{~kg} \mathrm{ha}^{-1} \mathrm{~K}\right)$, and sowing fertilization $\left(0\right.$ and $\left.30 \mathrm{~kg} \mathrm{ha}^{-1} \mathrm{~K}\right)$, composing a fully crossed factorial design $(5 \times$ 2 ), outlined in randomized blocks with four replications. Potassium chloride $(\mathrm{KCl})$ with insurance $58 \%$ of $\mathrm{K}_{2} \mathrm{O}$ was used as fertilizer.

Soybean cultivar NA5909 RG was sown at a density of 14 seeds $\mathrm{m}^{-1}$. The plots consisted of 10 rows, $8 \mathrm{~m}$ long, spaced $0.45 \mathrm{~m}$ apart. Excepting $\mathrm{K}$ fertilization, all cultural treatments from soybean sowing to harvest were carried out according to the guidelines for technologies, products and services (TPS) of Embrapa (2013), and according to the region and the soil chemical and physical analyses. The chemical and physical soil properties were: total organic C $23.2 \mathrm{~g} \mathrm{dm}^{-3}$ (Walkley-Black); $\mathrm{pH}\left(\mathrm{H}_{2} \mathrm{O}\right)$ (soil:water ratio of 1:2.5) $5.55 ; 15.3 \mathrm{mg} \mathrm{dm}^{-3} \mathrm{P}$ and $0.21 \mathrm{cmol}_{\mathrm{c}} \mathrm{dm}^{-3} \mathrm{~K}^{+}$(both extracted by Mehlich ${ }^{-1}$ ); $0.0 \mathrm{cmol}_{\mathrm{c}} \mathrm{dm}^{-3} \mathrm{Al}^{3+}, 6.4 \mathrm{cmol}_{\mathrm{c}} \mathrm{dm}^{-3} \mathrm{Ca}^{2+}$, and $1.4 \mathrm{cmol}_{\mathrm{c}} \mathrm{dm}^{-3}$ $\mathrm{Mg}^{2+}$ (both extracted by $\mathrm{KCl} 1 \mathrm{~mol} \mathrm{~L}^{-1}$ ); $\mathrm{CEC}$ (cation exchange capacity) $\mathrm{pH}_{7} 13.6 \mathrm{cmol}_{\mathrm{c}} \mathrm{dm}^{-3}$; base saturation (\%BS) $58 \%$; sand $175 \mathrm{~g} \mathrm{~kg}^{-1}$, silt $65 \mathrm{~g} \mathrm{~kg}^{-1}$, and clay $760 \mathrm{~g} \mathrm{~kg}^{-1}$.

$\mathrm{K}$ rates were applied manually performed on the soil surface at the $\mathrm{V}_{3}$ growth stage (Fehr \& Caviness, 1977) according to Pauletti and Motta (2017). The sowing fertilization was carried out along the sowing lines with a seeding machine coupled to a tractor. The fertilizer $(\mathrm{KCl})$ was placed at a distance of $0.05 \mathrm{~m}$ beside and $0.05 \mathrm{~m}$ below the seeds to avoid undesired saline effects during seed germination (Mortele et al., 2009).

Harvesting was performed manually at the $\mathrm{R}_{8}$ growth stage (Fehr \& Caviness, 1977). The yield per $9 \mathrm{~m}^{2}$ area was determined, the three external rows and $1.5 \mathrm{~m}$ at either end of the central rows were disregarded; only the four central rows of the experimental units were harvested. The thousand mass seed was determined according Brasil (2009) weighing eight replicates of 100 seeds, with a moisture correction of $130 \mathrm{~g}$ of water per $\mathrm{kg}$ of seed.

The electrical conductivity test was measured from 50 seeds per plot previously weighed and placed to soak in $180 \mathrm{~mL}$ plastic cups containing $75 \mathrm{~mL}$ of deionized water for a period of 24 hours at a constant temperature of $25^{\circ} \mathrm{C}$ (Brandão Jr. et al., 1997). After this incubation, it was possible to determine the electrical conductivity of the solution with Digimed CD 21 conductivity meter, its results expressed in $\mu \mathrm{S} \mathrm{cm}^{-1} \mathrm{~g}^{-1}$. For the $\mathrm{K}$ leaching test, 
50 seeds per plot were weighed and then immersed in $75 \mathrm{~mL}$ deionized water in plastic cups and placed in a germinator at a constant temperature of $30^{\circ} \mathrm{C}$ for 30 minutes. The cups were shaken before and after the time in the germinator, after about $30 \mathrm{~mL}$ were removed for determination of $\mathrm{K}$ using flame photometry Micronal B-462, its results were expressed of $\mathrm{mg}$ of leached $\mathrm{K}$ per $\mathrm{kg}$ of seed $\left(\mathrm{mg} \mathrm{kg}^{-1}\right)$. Both tests were performed in duplicates in each experimental plot.

The water content was determined by the forced air circulation drying oven method, at a constant temperature of $105 \pm 3{ }^{\circ} \mathrm{C}$, for a period of 24 hours. $25 \mathrm{~g}$ of seeds were weighed before placing them into the drying oven and weighed again after removing them from the drying oven (Brasil, 2009). The results were expressed as percent of water $(\%)$.

The seed density was determined according to Kryzanowski (2016). It was used a cylindrical vessel with 160.85 $\mathrm{cm}^{3}$, which, when filled, the contents were leveled and compacted by means of three beats of the cylindrical vessel on a rigid surface. After that, the mass was measured and results expressed in $\mathrm{g} \mathrm{dm}^{-3}$.

To determine oil and protein seed contents, the seeds harvested were previously oven dried with forced circulation at $60 \pm 1{ }^{\circ} \mathrm{C}$ until obtaining a constant mass in order to standardize the water content. Later, they were milled in a Willey type mill, obtaining the soybean meal with the husk.

Protein amount was determined by digestion of nitrogenous components in presence of heated concentrated $\mathrm{H}_{2} \mathrm{SO}_{4}$, together with a catalytic mixture (copper sulphate and selenium powder) according to the Kjeldahl Semi-micro method. To calculate the conversion of total nitrogen to proteins, factor 6.25 was used and the protein percentage was obtained based on the dry matter. The total oil content was extracted from the Soxhlet extractor apparatus and petroleum ether as solvent, with reflux of 6 hours, in which 2 sub-samples of $2 \mathrm{~g}$ from soybean meal were evaluated. The results were expressed as percentage of extracted oil determined by weighing difference.

All data of the variables were subjected to an analysis of basic statistic assumptions using the Shapiro-Wilk (error normality) and Bartlett (homogeneity of variances) tests ( $p>0.01)$. The two growing seasons and effects of the $\mathrm{K}$ rates, and sowing fertilization, as well as the possible interactions among the factors were evaluated together by the $\mathrm{F}$ test in the analysis of variance. The quantitative data referred to as rates were analyzed by means of regression, and beta coefficients subjected to the t-test, both in relation to the isolated factors and the possible rate interactions. All seed quality variables were subjected to Pearson's linear correlation analysis with soybean yield. For all statistical interpretations, a $5 \%$ probability $(\mathrm{p}<0.05)$ was used (Zimmermann, 2014).

\section{Results and Discussions}

\subsection{Electrical Conductivity, Potassium Leaching and Potassium Seed Content}

For all the variables of quality and seed production analyzed there were differences between growing seasons. In Figure 2 (A, B and C) are the results referring to variables electrical conductivity, $\mathrm{K}$ leaching and $\mathrm{K}$ seed content. Nonetheless, no interactions among treatments and growing season were shown. Seeds produced in the 2016/17 showed higher averages for electrical conductivity and K leaching when compared to the 2017/18. On the other hand, $\mathrm{K}$ seed content was higher for seeds produced in 2017/18.

These differences between the growing seasons may be associated with climatic events between the two growing seasons, mainly the rainfall patterns. In the $2016 / 17$ growing season, the cumulative rainfall was $715 \mathrm{~mm}$, while in the 2017/18 growing season, the total was $1097 \mathrm{~mm}$ (Figure 1). Furthermore, another factor contributing to this difference it was the storage period of the seeds of the 2016/17 growing season. The seeds harvested were stored until were submitted to the analyzes. Smaniotto et al. (2014) have indicated that different storage conditions such as time, temperature and environment can significantly alter quality tests, such as electrical conductivity. Batistella Filho (2012) applying K rates cited that water unbalance could negatively influence, especially when it occurs near the harvest. 


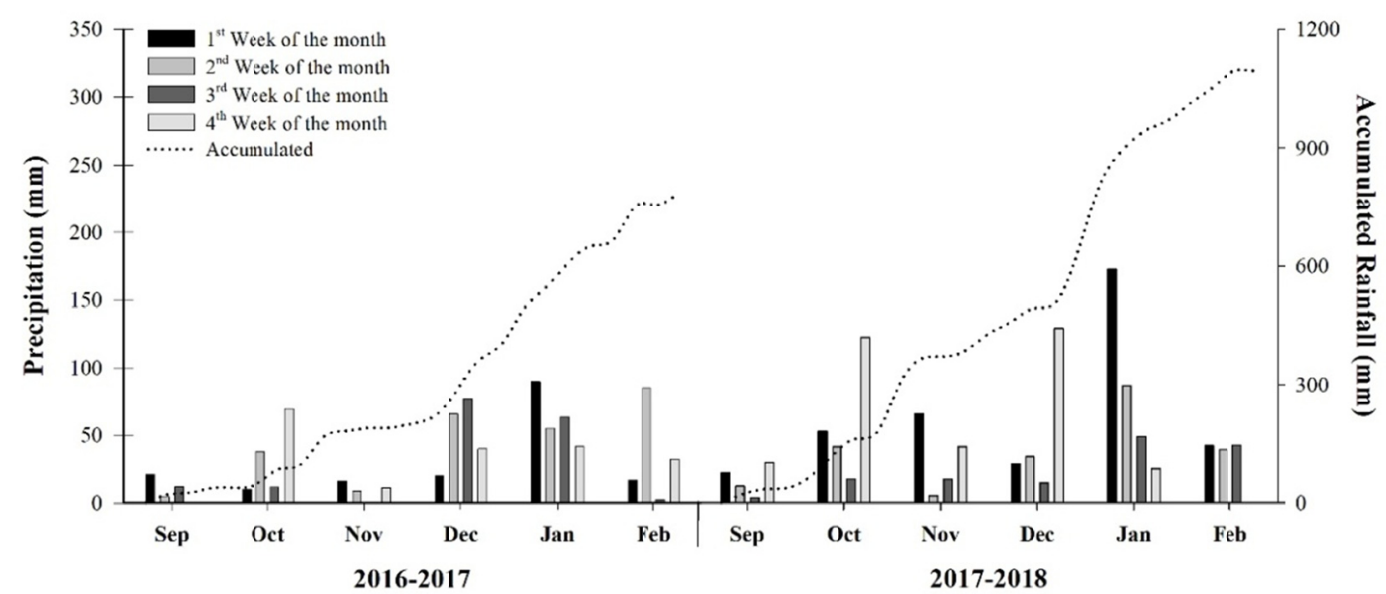

Figure 1. Weekly and accumulated rainfall during the experimental period 2016/2017 and 2017/2018

However, when analyzing each factor individually, there was significant difference for the rates (Figure 2A), being adjusted the linear regression model. For each $\mathrm{kg}$ of $\mathrm{K}$ applied to the soil the electrical conductivity of the seeds was reduced by $0.113 \mu \mathrm{S} \mathrm{cm}^{-1} \mathrm{~g}^{-1}$, in case of non-fertilization with $\mathrm{K}$, the value was $70.1 \mu \mathrm{S} \mathrm{cm}^{-1} \mathrm{~g}^{-1}$. The factor sowing fertilization there was no difference (Table 1). On the other hand, analyzing growing season 2017/18 no difference for treatment was found and the average obtained was $29.8 \mu \mathrm{S} \mathrm{cm}^{-1} \mathrm{~g}^{-1}$.

Electrical conductivity is a test related to the morphological and structural seed membranes integrity, and highest values are linked to structural disturbances, which will cause greatest exudation of cytoplasmic solutes, such as sugars, amino acids, organic acids, proteins, phenolic substances and inorganic ions (Rodrigues et., 2006) which increase seed electrical conductivity, especially during the imbibitions period (Fessel et al., 2010). Increases of seed electrical conductivity values occurs when there is loss of endomembranes selective permeability. From this, some post-harvest events, such as pathogen attack, mechanical damage and storage time, further damage seed quality. For soybean seed, the electrical conductivity of up to $60 \mu \mathrm{S} \mathrm{cm}^{-1} \mathrm{~g}^{-1}$ is considered of satisfactory vigor, on the other hand, 70 up to $80 \mu \mathrm{S} \mathrm{cm}^{-1} \mathrm{~g}^{-1}$ is considered average vigor (AOSA, 2002). The highest electrical conductivity observed was $70 \mu \mathrm{S} \mathrm{cm}^{-1} \mathrm{~g}^{-1}$, and even then, the value was within the average levels for this variable.

Under adverse and unfavorable conditions, $\mathrm{K}$ soil fertilization acts as an attenuating agent for these unwanted effects. These results corroborate Rossetto et al. (1997) stated that K fertilization improved seed quality only after a certain period of storage, although soon after the seed harvest there is no evidence in quality improvement.

Concerning K seed leaching test, there was also a difference between the years, in which the 2016/17 growing season differed and surpassed year 2017/18 for this variable. However, no interactions were recorded to K seed leaching. When analyzing the factor $\mathrm{K}$ rate singly, in 2016/17 growing season, a quadratic regression model was adjusted, by which rate of $94.2 \mathrm{~kg} \mathrm{ha}^{-1}$ of $\mathrm{K}$ applied in the soil promoted the highest $\mathrm{K}$ seeds leaching $(361.8 \mathrm{mg}$ $\mathrm{g}^{-1}$ ). While in 2017/18 growing season a linear regression model was adjusted, by which each $\mathrm{kg}$ of $\mathrm{K}$ applied increased the $\mathrm{K}$ seed leaching by $0.251 \mathrm{mg} \mathrm{g}^{-1}$

The K seed leaching test has been used as a seed quality index for several plant species (Marcos Filho, 2005). This test is based similarly to electrical conductivity test, with the benefit of being a easier and quicker to obtain results, although it only quantifies the $\mathrm{K}$, whereas the electrical conductivity quantifies the total of ions released by seed during the imbibition (Kituti et al., 2008).

The results among electrical conductivity and $\mathrm{K}$ leaching did not follow the same behavior. $\mathrm{K}$ leaching was up to the rate of $94.2 \mathrm{~kg}$ of $\mathrm{K}$, whereas the accumulation of $\mathrm{K}$ in the seed was linear positive (Figure 2C). Custódio and Marcos Filho (1997) reported that there was no association of the amount of $\mathrm{K}$ in the seeds and the $\mathrm{K}$ seed leaching during the imbibition process, although the results of this study do not corroborate this information. For the case of researches with potassium rates applied to the soil, which alter the $\mathrm{K}$ content in the seed and, in turn, the $\mathrm{K}$ leaching, the seed electrical conductivity was more adequate test for this kind of condition.

Regarding K seed content, interactions among the factors were not assessed, although there were differences for factor years and rates when analyzed separately in both growing seasons (Figure 2C). In 2016/17 each kg of K 
applied increased the $\mathrm{K}$ seed content by $0.005 \mathrm{~g} \mathrm{~kg}^{-1}$. On the other hand, in 2017/18 each $\mathrm{kg}$ of $\mathrm{K}$ per ha applied increased the $\mathrm{K}$ seed contend by $0.004 \mathrm{~g} \mathrm{~kg}^{-1}$ and the initial values were 16.90 and 19.05 for growing season 2016/17 and 2017/18 respectively. According to Gurgel et al. (2010) for the transport of photoassimilates in the phloem is necessary $\mathrm{K}$, therefore the increase of $\mathrm{K}$ in the seed is understandable since the seed is the main drain of the plant from a certain phenological scale.
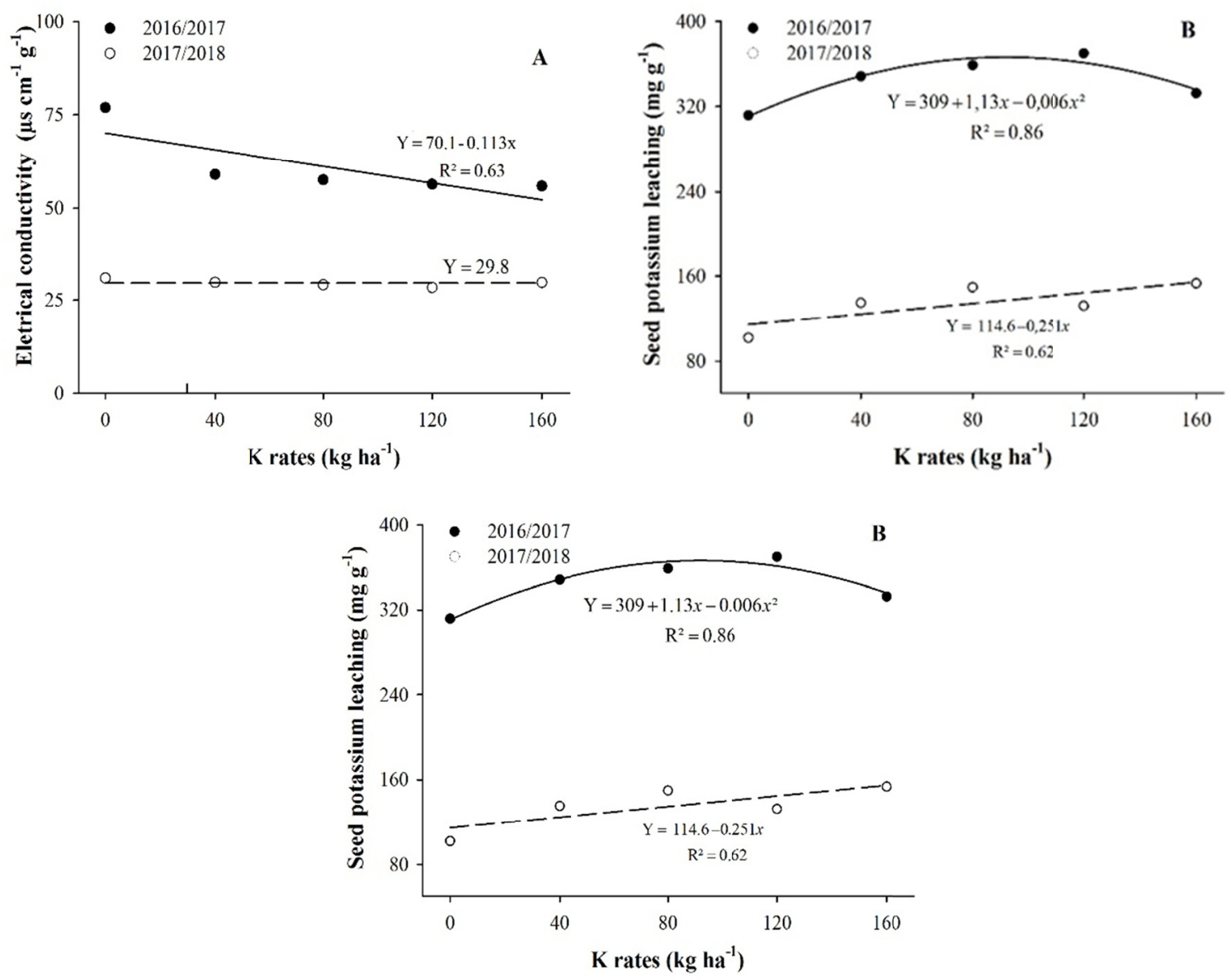

Figure 2. Electrical conductivity (A), and seed potassium leaching (B) and potassium seed content (C) of soybean in 2016/2017 and 2017/2018 after the application of different $\mathrm{K}$ rates. $*=$ significant at $5 \%$ probability

\subsection{Oil, Protein and Water Content}

For the variable protein seed content, there were no significant interactions among the evaluated factors, although when analyzing each factor alone there were differences for two growing season (Figure 3A). Averages of $37.69 \%$ and $32.67 \%$ of protein were observed in the seeds for the $2016 / 17$ and $2017 / 18$ growing season, respectively. Although seed protein varied among years, it was not affected for $\mathrm{K}$ rates. This may happened because of higher precipitation in 2017/18 which could negatively have influenced biological nitrogen fixation due to lower soil aeration (Pipolo et al., 2015).

Viega et al. (2010) observed reduction in protein contents with potassium rates increases and the minimum results were obtained in the rate of $160 \mathrm{~kg} \mathrm{ha}^{-1}$ of $\mathrm{K}$. These results corroborate those obtained by Tanaka et al. (1995) whose found a lower protein concentration in seeds, with potassium fertilization increases, although the authors argued that an increase in protein yield per unit area may have occurred. On the other hand, Haq and Malarino (2005) evaluated K and P fertilization in seed quality in 35 sites and showed that results for the protein content are inconsistent, and may or may not vary according to the $\mathrm{K}$ rates, depending on the conditions under which the soybean was grown.

Oil seed content was significantly altered, as a function of the rates of $\mathrm{K}$ applied, as well as for the different growing seasons (Figure 3B). The maximum oil content in the 2016/17 growing season was obtained with the 
rate of $97.4 \mathrm{~kg} \mathrm{ha}^{-1}$ of $\mathrm{K}$ corresponding to the oil content of $13.05 \%$. In 2017/18 growing season, the rate which provided the highest oil content (13.24\%) was $93.4 \mathrm{~kg} \mathrm{ha}^{-1}$ of $\mathrm{K}$.

In soybean crop, oil translocation to the seed depends on the presence of K (Mascarenhas et al., 1998), whereas this nutrient assists in photoassimilates transport to the seed and thus allows oil synthesis. Viega et al. (2010) obtained higher oil contents with the increase of the K rates, and when this authors tested $200 \mathrm{~kg} \mathrm{ha}^{-1}$ of K obtained oil contents above 19\%. Zambiazzi et al. (2017) studying application of K rates for different soybean cultivars in Minas Gerais state Brazil, also showed increases in oil seeds content of soybean.

Increases in seed oil content are not only beneficial for the production of vegetable oil and biofuels; in addition, oil content also interferes at soybean seed quality. Costa et al. (2001) found higher soybean seeds quality in the same place where the seeds had higher oil contents. This oil percentage is influenced by the environmental conditions where the crop was cultivated (Wilcox \& Cavens, 1992). Haq and Malarino (2005) cite K fertilization may interfere positively oil content as protein, corroborating the present study.

In Figure 3C, results presented refer to seeds water content. The quadratic regression model was adjusted for both growing seasons. The maximum value for seeds water content was obtained with $100 \mathrm{~kg} \mathrm{ha}^{-1} \mathrm{~K}$ application for 2016/17 growing season and $89.2 \mathrm{~kg} \mathrm{ha}^{-1} \mathrm{~K}$ application for 2017/18 growing season, corresponding to $9.2 \%$ and $10.1 \%$ seeds water content, respectively.

Seeds with higher concentrations of $\mathrm{K}$ tend to retain more water, resulting in a higher water content. Blackman et al. (1992) emphasized that the seed desiccation tolerance is associated to the levels of the solutes present in it. On the other hand, water retention in the seed may cause damage at harvest time. According to Ribeiro et al. (2007), water content influences seeds deformation, when subjected to compression; the smaller the water content the greater the force required to deform the seed.
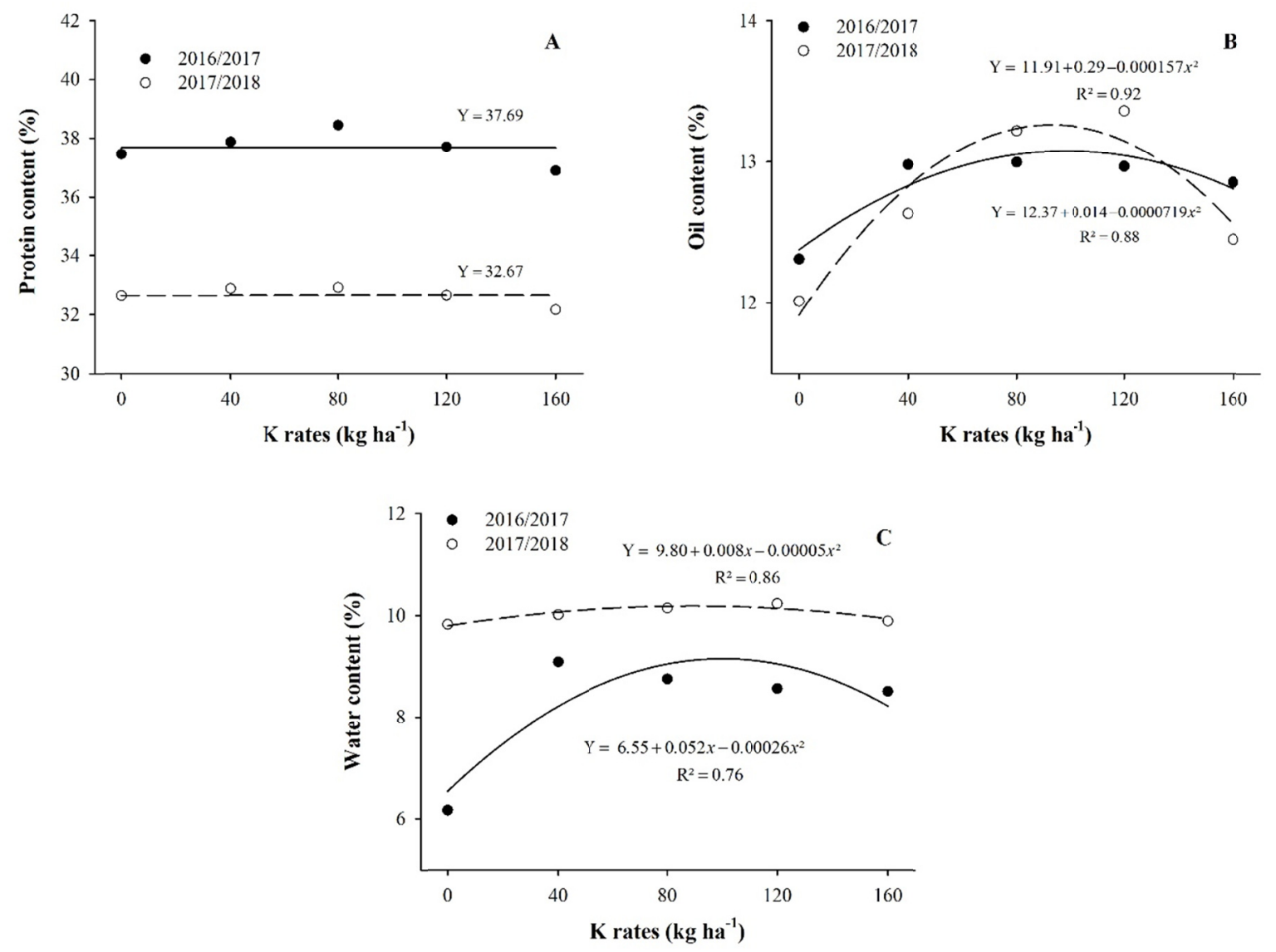

Figure 3. Protein content (A), oil content (B), and water content (C) of soybean in 2016/2017 and 2017/2018 after the application of different $\mathrm{K}$ rates. $*=$ significant at $5 \%$ probability 


\subsection{Seed Density, Thousand Seeds Mass and Yield}

Interactions among the factors were not verified to variable seed density, although when analyzed the factors singly there were differences among growing seasons and rates. In 2017/18 growing season obtained higher averages than previous growing season for seed density (Figure 4A). In the 2016/17 growing season, was adjusted a quadratic regression model, in which the highest seed density $\left(728 \mathrm{~g} \mathrm{dm}^{-3}\right)$ was reached with the rate of $106.7 \mathrm{~kg} \mathrm{ha}^{-1}$ of K applied. On the other hand, no changes in seed density was recorded in 2017/18 growing season and the overall mean density was $837 \mathrm{~g} \mathrm{dm}^{-3}$. According to Embrapa (2016), the average seed density in Paraná State Brazil was approximately $708 \mathrm{~g} \mathrm{~cm}^{-3}$.

Seed density is the ratio of mass to volume (Silva, 2008). Its increase occurs through the occupation of empty spaces of the seeds by chemical compounds like oil and protein and is influenced by the degree of seeds maturity and humidity (Bezerra et al., 2004). This variable is important because it may have correlations with yield effects (Table 2) which requires more in-depth studies on its behavior through environmental changes, genetic basis and fertilization, in this case $\mathrm{K}$ fertilization.

Figure 4B shows the results of seed mass produced. There were differences among the harvests, and the seed mass in the 2016/17 growing season differed and was higher than 2017/18 seeds. When evaluating the individual growing season a significant quadratic regression model was adjusted for the 2016/17, which the rate of $116.3 \mathrm{~kg}$ $\mathrm{ha}^{-1}$ of K applied provided a higher seed mass. Pereira et al. (2016), Martins et al. (2013), and Serafim et al. (2012) also observed increases of seed mass after soil K application. Fertilization with $\mathrm{K}$ increases the number of pods per plant and the size of seeds (Malavolta, 2006). Production of lighter seeds may affect yield, since this is one of the main components of soybean production. Furthermore, $\mathrm{K}$ acts in the redistribution of photoassimilates to the seeds, an important phenomenon for the formation of seeds with quality (Mascarenhas et al., 1988; Usherwood et al., 1994).
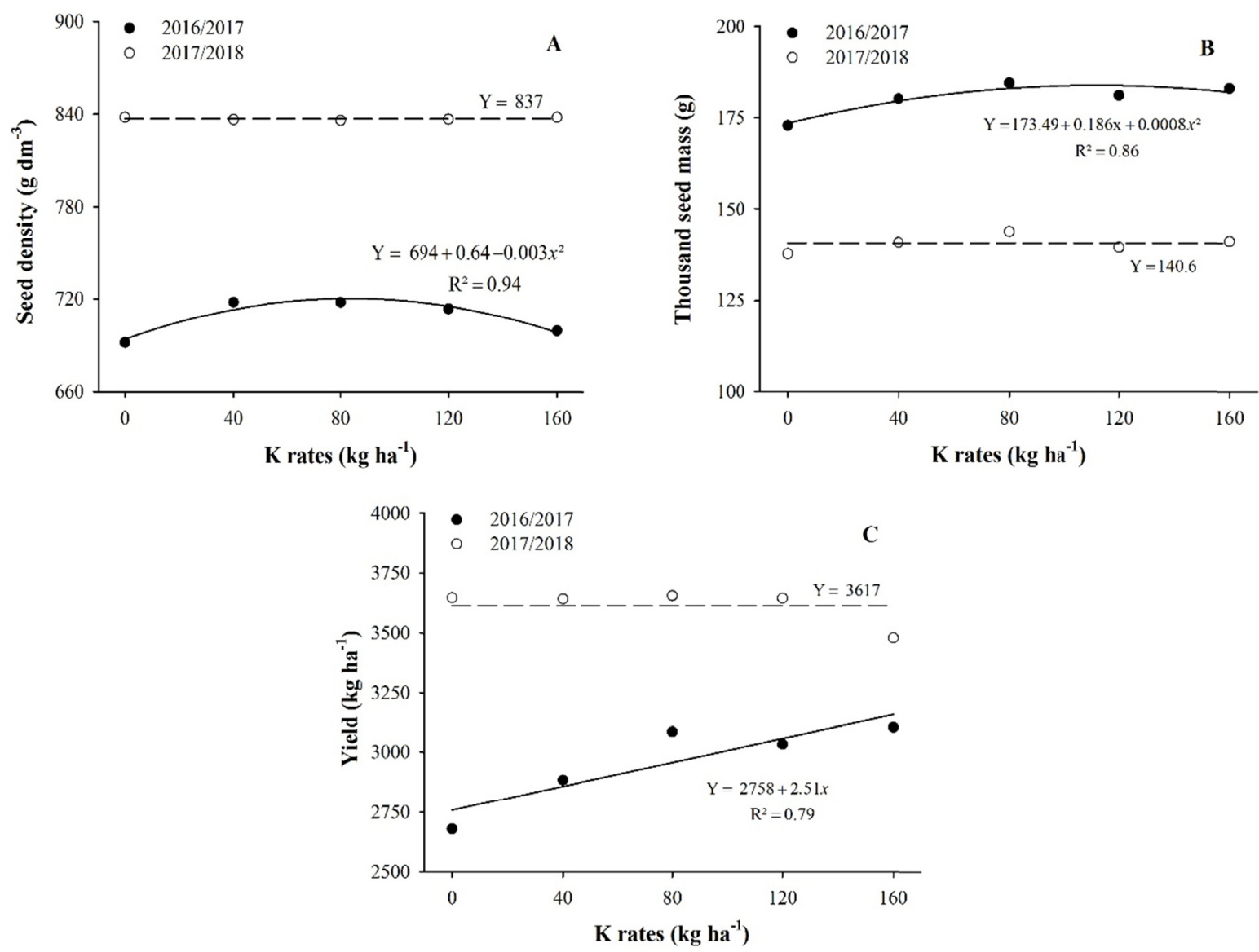

Figure 4. Seed density (A), thousand mass seed (B), and yield (C) of soybean in 2016/2017and 2017/2018 after the application of different $\mathrm{K}$ rates. ${ }^{*}=$ significant at $5 \%$ probability 
In the 2017/18 growing season there were no differences for the seed mass, and the average obtained was 140.6 g. One of the possible causes may have been the lower water availability in this growing season, since some authors indicated that the plant responses to available $\mathrm{K}$ are clearer in adverse conditions mainly in lower water availability (Sangakkara et al., 2001; Wang et al., 2013; Zörb et al., 2014; Esper Neto et al., 2018).

A significant difference was also pointed in seed yield between growing seasons. However, only in the 2016/17 growing season was affected by $\mathrm{K}$ rate (Figure $4 \mathrm{C}$ ) and interactions among the factors were not assessed. The linear regression model was adjusted, in which each $\mathrm{kg}$ of $\mathrm{K}$ applied to the soil increased yield in $2.51 \mathrm{~kg}$ of soybean seeds. On the other hand, in 2017/18 growing season there were no statically differences and the general average was $3617 \mathrm{~kg} \mathrm{ha}^{-1}$, which corroborates the greater responses of the crops to $\mathrm{K}$ fertilization under unfavorable conditions like lower rainfall.

Table 1 shows the averages of all the response variables separated by crop season for the sowing fertilization factor. There were no significant statistical differences among application of sowing fertilization with $30 \mathrm{~kg} \mathrm{ha}^{-1}$ of $\mathrm{K}$, and the non-performance of this practice, both for seed quality tests and for components of seed yield.

Table 1. Means of seed quality and yield for the sowing fertilization factor

\begin{tabular}{|c|c|c|c|c|c|c|c|c|c|}
\hline Treatment & YIE & $\mathrm{EC}$ & KLEA & $\mathrm{KC}$ & PTN & OIL & $\mathrm{WC}$ & DEN & TMS \\
\hline & $\mathrm{kg} \mathrm{ha}^{-1}$ & $\mu \mathrm{S} \mathrm{cm}^{-1} \mathrm{~g}^{-1}$ & $\mathrm{mg} \mathrm{kg}^{-1}$ & $\mathrm{~g} \mathrm{~kg}^{-1}$ & -------- & \% - - & - & $\mathrm{g} \mathrm{dm}^{-3}$ & $\mathrm{~g}$ \\
\hline \multicolumn{10}{|l|}{$2016 / 2017$} \\
\hline SF & $2986.5 \mathrm{~A}$ & $63.5 \mathrm{~A}$ & $343.5 \mathrm{~A}$ & $17.0 \mathrm{~A}$ & $38.0 \mathrm{~A}$ & $12.9 \mathrm{~A}$ & $7.3 \mathrm{~A}$ & $698.0 \mathrm{~A}$ & $181.6 \mathrm{~A}$ \\
\hline WSF & $2932.6 \mathrm{~A}$ & $58.4 \mathrm{~A}$ & $335.4 \mathrm{~A}$ & $17.6 \mathrm{~A}$ & $37.4 \mathrm{~A}$ & $12.7 \mathrm{~A}$ & 7.1A & 708.7A & $179.2 \mathrm{~A}$ \\
\hline \multicolumn{10}{|l|}{$2017 / 2018$} \\
\hline SF & $3646.3 \mathrm{~A}$ & $29.6 \mathrm{~A}$ & $132.0 \mathrm{~A}$ & $19.2 \mathrm{~A}$ & $32.6 \mathrm{~A}$ & $12.6 \mathrm{~A}$ & $9.2 \mathrm{~A}$ & $835.6 \mathrm{~A}$ & $140.2 \mathrm{~A}$ \\
\hline WSF & $3588.0 \mathrm{~A}$ & $29.8^{\mathrm{a}}$ & $137.5 \mathrm{~A}$ & $19.7 \mathrm{~A}$ & $32.8 \mathrm{~A}$ & $12.8 \mathrm{~A}$ & 8.9A & $838.6 \mathrm{~A}$ & 141.1A \\
\hline
\end{tabular}

Note. $\mathrm{SF}=$ Seeding fertilization; $\mathrm{WSF}=$ Without seeding fertilization; YIE $=$ soybean yield; EC $=$ electrical conductivity; KLEA = Potassium leaching; $\mathrm{KC}=$ potassium content; $\mathrm{PTN}=$ Protein content; OIL = oil content; $\mathrm{WC}=$ water content; DEN = seed density; TMS = thousand mass seed. Averages followed by the same capital letter in the column, do not differ from each other, $5 \%$ of probability by the $\mathrm{F}$ test.

\subsection{Correlations}

Table 2 shows Pearson's correlation analysis. There was no significance for any variable, with oil content. The highest correlations with yield were YIE $\times \mathrm{EC}(\mathrm{r}=-0.72)$ in which the higher seed electrical conductivity, the lower the yield. Castro et al. (2017) found lower values of electrical conductivity in the places where presented better physiological quality of soybean seeds, which were attested by other tests such as germination, vigor and emergence.

Another correlation that stood out was between YIE $\times$ DEN $(r=0.70)$ which is justifiable since density is a component of production. According to Fonseca (2007) plants well-nourished during their development present higher density or larger size of the seed.

Table 2. Simple linear correlation matrix between soybean yield and the qualities seed parameters

\begin{tabular}{|c|c|c|c|c|c|c|c|c|c|}
\hline \multirow{2}{*}{ Parameters } & \multicolumn{9}{|c|}{ Correlation Coefficient } \\
\hline & YIE & $\mathrm{EC}$ & KLEA & $\mathrm{KC}$ & PTN & OIL & WC & DEN & TMS \\
\hline YIE & & $-0.72^{*}$ & $-0.66^{*}$ & $0.62^{*}$ & $-0.64^{*}$ & $0.12^{\mathrm{ns}}$ & $0.53^{*}$ & $0.70^{*}$ & $-0.58^{*}$ \\
\hline $\mathrm{EC}$ & & & $0.81^{*}$ & $-0.82^{*}$ & $0.75^{*}$ & $-0.04^{\mathrm{ns}}$ & $-0.67^{*}$ & $-0.87^{*}$ & $0.78^{*}$ \\
\hline KLEA & & & & $-0.81^{*}$ & $0.79^{*}$ & $0.15^{\mathrm{ns}}$ & $-0.48^{*}$ & $-0.88^{*}$ & $0.91^{*}$ \\
\hline $\mathrm{KC}$ & & & & & $-0.74^{*}$ & $0.01^{\mathrm{ns}}$ & $0.43^{*}$ & $0.82^{*}$ & $-0.79^{*}$ \\
\hline PTN & & & & & & $0.15^{\mathrm{ns}}$ & $-0.49^{*}$ & $-0.76^{*}$ & $0.80^{*}$ \\
\hline OIL & & & & & & & $-0.02^{\mathrm{ns}}$ & $-0.03^{\mathrm{ns}}$ & $0.13^{\mathrm{ns}}$ \\
\hline $\mathrm{WC}$ & & & & & & & & $0.61^{*}$ & $-0.56^{*}$ \\
\hline DEN & & & & & & & & & $-0.87^{*}$ \\
\hline
\end{tabular}

Note. $\mathrm{YIE}=$ soybean yield; $\mathrm{EC}=$ electrical conductivity $\mathrm{KLEA}=$ Potassium leaching; $\mathrm{KC}=$ potassium content; $\mathrm{PTN}=$ Protein content; OIL $=$ oil content; $\mathrm{WC}=$ water content; $\mathrm{DEN}=$ seed density; TMS $=$ thousand mass seed. $*=$ significant at $5 \%$ probability; ns $=$ non-significant at $5 \%$ probability. 


\section{Conclusions}

Seed quality is greatly affected by higher K in soil as well as K fertilization tends to be helpful to enhance seed quality under low water availability.

The response of seeds oil content was larger than protein content after $\mathrm{K}$ fertilization. The sowing fertilization with $30 \mathrm{~kg} \mathrm{ha}^{-1}$ had no influence on seeds the quality produced.

The $\mathrm{K}$ leaching test and electrical conductivity despite having the same principles did not complement it selves in the situation of this study, since the fertilization increased the absolute seed $\mathrm{K}$ contents. Therefore, the electrical conductivity test was more reliable than $\mathrm{K}$ leaching test.

Despite soil K levels suitable for soybeans before the experiment, seed yield and mass increased after $\mathrm{K}$ fertilization for 2016/17 growing season. Accordingly, K fertilization could be a pathway to reach high seed quality in soybean crop production.

\section{References}

Albrecht, L. P., Braccini, A. L., Ávila, M. R., Suzuki, L. S., Scapim, C. A., \& Barbosa, M. C. (2008). Teores de óleo, proteínas e produtividade de soja em função da antecipação da semeadura na região oeste do Paraná. Bragantia, 67(4). https://doi.org/10.1590/S0006-87052008000400008

Alvares, C. A., Stape, J. L., Sentelhas, P. C., de Moraes, G., Leonardo, J., \& Sparovek, G. (2013). Köppen's climate classification map for Brazil. Meteorologische Zeitschrift, 22(6), 711-728. https://doi.org/10.1127/ 0941-2948/2013/0507

Association of Official Seed Analysts. (2002). Seed vigor testing handbook. Lincoln: AOSA.

Basseto, M. A., Ceresini, P. C., \& Valério Filho, W. V. (2007). Severidade da mela da soja causada por Rhizoctonia solani AG-1 IA em função de doses de potássio. Summa Phytopathologica, 33, 56-62. https://doi.org/10.1590/S0100-54052007000100008

Batistella Filho, F. (2012). Adubação com fósforo e potássio para produção e qualidade de sementes de soja. Pesquisa Agropecuária Brasileira, 48(7), 783-790. htpps://doi.org/10.1590/S0100-204X2013000700011

Bernardi, A. C. C., Oliveira, J. R., Leandro, W. M., Mesquita, T. G. S., Freitas, P. L., \& Carvalho, M. C. S. (2009). Doses e formas de aplicação da adubação potássica na rotação soja, milheto e algodão em sistema plantio direto. Pesquisa Agropecuária Tropical, 39(2), 158-167.

Bezerra, A. M. E, Momenté, V. G. \& Medeiros Filho, S. (2004). Germinação de sementes e desenvolvimento de plântulas de moringa (Moringa oleifera) em função do peso da semente e do tipo de substrato. Horticultura Brasileira, 22(2), 295-299. https://doi.org/10.1590/S0102-05362004000200026

Blackman, S. A., Obendorf, R. L., \& Leopold, A. C. (1992). Maturation proteins and sugars in desiccation tolerance of developing soybean seeds. Plant Physiology, 100(1), 225-230. https://doi.org/10.1104/pp.100. 1.225

Brandão, J. R. D. S., Ribeiro, D., Bernardino Filho, J. R., \& VIEIRA, m. (1997). Adequação do teste de condutividade elétrica para determinar a qualidade fisiológica de sementes. Informativo ABRATES, 7(1/2), 184.

Brasil. (2009). Ministério da Agricultura, Pecuária e Abastecimento. Regras para análise de sementes. Brasília: Secretaria de Defesa Agropecuária.

Cardoso, A. M., Cividanes, F. J., \& Natale, W. (2002). Influência da adubação fosfatada-potássica na ocorrência de pragas na cultura da soja. Neotropical Entomology, 31(3), 441-444. https://doi.org/10.1590/S1519-566 X2002000300014

Castro, D. C., Bruzi, A. T., Zambiazzi, E. V., Rezende, P. M., Zuffo, A. M, Sales, A. P., .. Bianchi, M. C. (2017). Qualidade fisiológica e expressão enzimática de sementes de soja RR. Revista de Ciências Agrárias, 40(1), 222-235. https://doi.org/10.19084/RCA16054

CONAB (Companhia Nacional de Abastecimento). (2018). Acompanhamento de safra brasileira: Grãos, décimo levantamento. Brasília, Brazil. Retrieved from file://C:/Users/Usuario/Downloads/BoletimZGraosZjulho Z2018\%20(1).pdf

Costa, N. D., Mesquita, C. D. M., Maurina, A. C., França Neto, J. D. B., Pereira, J. E., Bordingnon, J. R., \& Henning, A. A. (2001). Efeito da colheita mecânica da soja nas características físicas, fisiológicas e 
químicas das sementes em três estados do Brasil. Revista Brasileira de Sementes, 23(1), 140-145. https://doi.org/10.17801/0101-3122/rbs.v23n1p140-145

Custódio, C. C., \& Marcos Filho, J. (1997). Potassium leachate test for the evaluation of soybean seed physiological quality. Seed Science and Technology, 25(3), 549-564.

Embrapa (Empresa Brasileira de Pesquisa Agropecuária). (2013). Tecnologias de produção de soja-Região central do Brasil (Sistema de Produção 16). Londrina: Embrapa.

Embrapa (Empresa Brasileira de Pesquisa Agropecuária). (2016). Qualidade de sementes e grãos comerciais de soja no Brasil-safra 2014/15 (Documento 378). Londrina: Embrapa.

Esper Neto, M., Minato, E. A., Besen, M. R., Inoue, T. T., \& Batista, M. A. (2018). Biometric Responses of Soybean to Different Potassium Fertilization Management Practices in Years with High and Low Precipitation. Revista Brasileira Ciência do Solo, 42(1). https://doi.org/10.1590/18069657rbcs20170305

Fehr, W. R., \& Caviness, C. E. (1977). Stages of soybean development. Special Ames: Iowa State University.

Fessel, S. A., Panobianco, M., Souza, C. R., \& Vieira, R. D. (2010). Teste de condutividade elétrica em sementes de soja armazenadas sob diferentes temperaturas. Bragantia, 69(1), 207-214. https://doi.org/10.1590/ S0006-87052010000100026

Foloni, J. S. S., \& Rosolem, C. A. (2008). Produtividade e acúmulo de potássio na soja em função da antecipação da adubação potássica no sistema plantio direto. Revista Brasileira de Ciência do Solo, 32(1) 1549. https://doi.org/10.1590/S0100-06832008000400019

Fonseca, N. R. (2007). Qualidade fisiológica e desempenho agronômico de soja em função do tamanho das sementes (Doctoral thesis, Universidade Estadual Paulista, Botucatu, Brazil).

Gonçalves Junior, A. C., Nacke, H., Marengoni, N. G., De Carvalho, E. A., \& Coelho, G. F. (2010). Produtividade e componentes de produção da soja adubada com diferentes doses de fósforo, potássio e zinco. Ciência e Agrotecnologia, 34(3), 660-666. https://doi.org/10.1590/S1413-70542010000300019

Guareschi, R. F., Gazolla, P. R., Souchie, E. L., \& Rocha, A. C. (2008). Adubação fosfatada e potássica na semeadura e a lanço antecipada na cultura da soja cultivada em solo de Cerrado. Semina: Ciências Agrárias, 29(4), 769-774. https://doi.org/10.5433/1679-0359

Gurgel, M. T., Gheyi, H. R., \& Oliveira, F. H. T (2010). Acúmulo de matéria seca e nutrientes em meloeiro produzido sob estresse salino e doses de potássio. Revista Ciência Agronômica, 41(1), 18-28.

Haq, M. U., \& Mallarino, A. P. (2005). Response of soybean grain oil and protein concentrations to foliar and soil fertilization. Agronomy Journal, 97(3), 910-918. http://doi.org/10.2134/agronj2004.0215

Khan, H. Z., Malik, M. A., Saleem, M. F., \& Aziz, I. (2004). Effect of different potassium fertilization levels on growth, seed yield and oil contents of canola (Brassica napus L.). International Journal of Agriculture \& Biology, 6(3), 557-559.

Kikuti, H., Medina, P. F., Kikuti, A. L. P., \& Ramos, N. P. (2008). Teste de lixiviação de potássio para avaliação do vigor de sementes de amendoim. Revista Brasileira de Sementes, 30(1), 10-18. https://doi.org/ $10.1590 / \mathrm{S} 0101-31222008000100002$

Krzyzanowski, F. C. (2016). Qualidade de sementes e grãos comerciais de soja no Brasil-safra 2014/2015: Características fisicas da semente: Dano mecânico não aparente, densidade e peso de 1000 sementes (Documento 378, pp. 49-59). Embrapa, Londrina.

Linzmeyer Junior, R., Guimarães, V. F., Santos, D., \& Bencke, M. H. (2008). Influência de retardante vegetal e densidades de plantas sobre o crescimento, acamamento e produtividade da soja. Acta Scientiarum. Agronomy, 30(3). https://doi.org/10.4025/actasciagron.v30i3.3547

Malavolta, E. (2006). Manual de nutrição mineral de plantas. Piracicaba: Agronômica Ceres.

Marcos Filho, J. (2005). Fisiologia de sementes de plantas cultivadas (p. 495). Piracicaba: Fealq.

Marschner, H. (1995). Mineral nutrition of higher plants (2nd ed., pp. 347-364). Londres, Academic Press.

Martins, I. S., Hanauer, R., Santos, A. S., Martins, I. S., \& Ferreira, I. (2013). Produtividade de soja sob aplicação de cloreto de potássio em pré-plantio e pós plantio. Nucleus, 10(2), 275-280. https://doi.org/ $10.3738 / 1982.2278 .951$ 
Mascarenhas, H. A. A., Bulisani, E. A., Miranda, M. A. C., Pereira, J. C. V. N. A., \& Braga, N. R. (1988). Deficiência de potássio em soja no estado de São Paulo: Melhor entendimento do problema e possíveis soluções. Informações Agronômicas, 1-4.

Moterle, L. M., Lopes, P. de C., Braccini, A. L., \& Scapim, C. A. (2009). Influência da adubação com fósforo e potássio na emergência das plântulas e produtividade da cultura da soja. Revista Ciência Agronômica, 40(2) 256-265.

Pauletti, V., \& Motta, A. C. V. (2017). Manual de adubação e calagem para o estado do Paraná. Curitiba: Sociedade Brasileira de Ciência do Solo, Núcleo Estadual Paraná.

Pedroso Neto, J. C., \& Rezende, P. M. (2005). Doses e modos de aplicação de potássio na produtividade de grãos e qualidade de semente de soja (Glycine max (L.), Merrill). FAZU em Revista, 5(2), 27-36.

Pereira, C. S., Freitas, A. A., Chapla, M. V., \& Lange, A. (2016). Doses de potássio com a presença de enxofre na cultura da soja. Global Science and Technology, 9(1) 22-32. https://doi.org/10.14688/1984-3801/gst.v9n1 p22-32

Petter, F. A., Ursulino Alves, A., Alves da Silva, J., de Almeida Cardoso, E., Ferreira Alixandre, T., de Almeida, F. A., \& Pereira Pacheco, L. (2014). Produtividade e qualidade de sementes de soja em função de doses e épocas de aplicação de potássio. Semina: Ciências Agrárias, 35(1). https://doi.org/10.5433/1679-0359.2014 v35n $1 \mathrm{p} 89$

Pipolo, A. E., Hungria, M., Franchini, J. C., Balbinot Junior, A. A., Debiasi, H., \& Mandarino, J. M. G. (2015). Teores de óleo e proteina em soja: Fatores envolvidos e qualidade para a indústria (Comunicado Técnico 86). Londrina: Embrapa Soja.

Ribeiro, D. M., Corrêa, P. C., Furtado, B. F., Goneli, A. L., \& Resende, O. (2007). Propriedades mecânicas dos grãos de soja em função do teor de água. Ciência e Tecnologia Pós-colheira, 27(2), 493-500. https://doi.org/ $10.1590 / \mathrm{S} 0100-69162007000300019$

Rodrigues, M. B. C., Villela, F. A., Tillmann, M. A. A., \& Carvalho, R. (2006). Pré-hidratação em sementes de soja e eficiência do teste de condutividade elétrica. Revista Brasileira de Sementes, 28(2), 168-181. https://doi.org/10.1590/S0101-31222006000200023

Rossetto, C. A. V., Novembre, A. D., Dal, C., Marcos Filho J., Silva, W. R., \& Nakagawa, J. (1997). Efeito da disponibilidade hídrica do substrato, da qualidade fisiológica e do teor de água inicial das sementes de soja no processo de germinação. Scientia Agricola, Piracicaba, 54(1/2), 97-105. https://doi.org/10.1590/S010390161997000100014

Sale, P. W. G., \& Campbell, L. C. (1986). Yield and composition of soybean seed as a function of potassium supply. Plant and Soil, 96(3), 317-325. https://doi.org/10.1007/BF02375136

Sangakkara, U. R., Frehner, M., \& Nösberger, J. (2001). Influence of soil moisture and fertilizer potassium on the vegetative growth of mungbean (Vigna radiata L. Wilczek) and cowpea (Vigna unguiculata L. Walp). Journal of Agronomy and Crop Science, 186(2), 73-81. https://doi.org/10.1046/j.1439-037X.2001.00433.x

Serafim, M. E., Ono, F. B., Zeviani, W. M., Novelino, J. O., \& Silva, J. V. (2012). Umidade do solo e doses de potássio na cultura da soja. Revista Ciência Agronômica, 43(2), 222-227. https://doi.org/10.1590/S1806-669 02012000200003

Silva, L. A. S. (2008). Herança e relações genéticas entre densidade da semente, teores de proteína e óleo e produtividade em soja (Doctoral thesis, Universidade de São Paulo, Piracicaba, Brazil).

Smaniotto, T. A. S., Resende, O., Marçal, K. A. F., Oliveira, D. E. C., \& Simon, G. A. (2014). Qualidade fisiológica das sementes de soja armazenadas em diferentes condições. Revista Brasileira de Engenharia Agricola e Ambiental, 18(4), 446-453. https://doi.org/10.1590/S1415-43662014000400013

Snyder, C., \& Ashlock, L. O. (1996). Late-season potassium deficiency symptoms in Southern soybeans. Better Crops With Plant Food, 80(1), 10-11.

Tanaka, R. T., Mascarenhas, H. A. A., Arce, M. A. R., \& Gallo, P. B. (1995). Concentração e produtividade de óleo e proteína de soja em função da adubação potássica e da calagem. Pesquisa Agropecuária Brasileira, 30(4), 463-469.

Toledo, M. Z., Castro, G. S. A., Crusciol, C. A. C., Soratto, R. P., Nakagawa, J., \& Cavariani, C. (2011). Physiological quality of soybean and wheat seeds produced with alternative potassium sources. Revista Brasileira de sementes, 33(2), 363-371. https://doi.org/10.1590/S0101-31222011000200019 
Usherwood, N. R. (1994). Potassium interactions and balanced plant nutrition. Better Crops With Food, 77(1), 26-27.

Veiga, A. D., Von Pinho, E. V. R., Veiga, A. D., Pereira, P. H. A. R., Oliveira, K. C., \& Von Pinho, R. G. (2010). Influência do potássio e da calagem na composição química, qualidade fisiológica e na atividade enzimática de sementes de soja. Ciência e Agrotecnologia, 34(4), 953-960. https://doi.org/10.1590/S1413-7054201000 0400022

Wang, M., Zheng, Q., Shen, Q., \& Guo, S. (2013). The critical role of potassium in plant stress response. International Journal of Molecular Sciences, 14(4), 7370-7390. https://doi.org/10.3390/ijms14047370

Westgate, M. E. E. Piper, W. D. Batchelor, \&. Hurburgh, Junior, C. R. (1999). Effects of cultural and environmental conditions during soybean growth on nutritive value of soy products. Proc. Global Soy Forum, American Soybean Association, St. Louis.

Wilcox, J. R., \& Cavins, J. F. (1992). Normal and low lenolenic acid soybean strains response to planting date. Crop Science, 32(5), 1248-1251. https://doi.org/10.2135/cropsci1994.0011183X003400050020x

Zambiazzi, E. V., Bruzi, A. T., Zuffo, A. M., Soares, I. O., Mendes, A. E. S., Teresani, A. L. R., ... Moreira, S. G. (2017). Desempenho agronómico e qualidade sanitária de sementes de soja em resposta à adubação potássica. Revista de Ciências Agrárias, 40(3), 543-553. https://doi.org/10.19084/RCA16055

Zimmermann, F. J. P. (2014). Estatística aplicada à pesquisa agrícola (2nd ed.). Brasília, DF.Embrapa.

Zorb, C., Senbayram, M., \& Peiter, E. (2014). Potassium in agriculture-status and perspectives. Jounal of Plant Physiology, 171, 656669. https://doi.org/10.1016/j.jplph.2013.08.008

\section{Copyrights}

Copyright for this article is retained by the author(s), with first publication rights granted to the journal.

This is an open-access article distributed under the terms and conditions of the Creative Commons Attribution license (http://creativecommons.org/licenses/by/4.0/). 